\title{
KATARZYNA LIŻYŃSKA
}

ORCID: 0000-0002-9666-1019

Uniwersytet Wrocławski

\section{PROBACJA W WYKROCZENIACH - O POTRZEBIE WARUNKOWEGO ZAWIESZENIA WYKONANIA KARY ARESZTU}

\begin{abstract}
Abstrakt: Warunkowe zawieszenie wykonania kary aresztu jest jedynym środkiem probacyjnym w wykroczeniach. Nie budzi wątpliwości stwierdzenie, że nie jest koniecznym warunkiem odbycie przez sprawcę kary, by cele kary, jak też postępowania w sprawie o wykroczenie zostały osiągnięte. Jednak szersza analiza omawianego środka probacyjnego wykazuje, że utrzymanie warunkowego zawieszenia wykonania kary aresztu w kodeksie wykroczeń jest wątpliwe. Przemawia za tym sprzeczność przesłanek stosowania kary aresztu i omawianej instytucji, jak również marginalne wykorzystywanie tej instytucji w praktyce.
\end{abstract}

Słowa kluczowe: wykroczenia, środek probacyjny, kara aresztu, warunkowe zawieszenie wykonania kary, obowiązek probacyjny, okres próby

Niewątpliwym celem kary są społecznie pożądane zjawiska, które winny zostać osiągnięte przez poddanie sprawcy karze kryminalnej. Kara winna być wymierzana w sposób racjonalny, zatem w taki, by założenia ujęte w celach kary (uczynienie zadość sprawiedliwości, naprawienie szkody spowodowanej przestępstwem, prewencja szczególna lub ogólna) urzeczywistniły się w zachowaniu sprawcy po jej zrealizowaniu. Nie zawsze jednak wykonanie kary jest jedyną możliwością urzeczywistnienia jej celów. Dużą rolę we współczesnych systemach prawnokarnych, w tym w ustawodawstwie polskim, odgrywa instytucja probacji, sprowadzająca się do niewprowadzania do wykonania w całości lub częściowej rezygnacji z kontynuowania odbywania kary z jednoczesnym poddaniem sprawcy próbie. Różnorodność form probacji w prawie karnym poszczególnych krajów ${ }^{1}$ wynika z tradycji i zróżnicowanych założeń prawnoustrojowych, a także różnych koncepcji politycznokryminalnych. Jak podkreśla Andrzej Marek, wśród tej różnorodności koncepcji jedno wydaje się cechą wspólną, a mianowicie przekonanie

${ }^{1}$ Szerzej na ten temat A. Marek, [w:] Kary i środki karne, t. 6. Poddanie sprawcy próbie, red. M. Melezini, Warszawa 2010, s. 929 n. 
o konieczności unikania zbędnego stosowania kary pozbawienia wolności (aresztu - K.L.) w tych wszystkich sytuacjach, w których efekty prewencyjno-wychowawcze można osiągnąc za pomocą mechanizmów oddziaływania na sprawców przestępstw (wykroczeń - K.L.) w warunkach wolnościowych, z poddaniem ich celowo ukształtowanym obowiązkom próby ${ }^{2}$. Termin probacja wywodzi się z łacińskiego słowa probare, co oznacza „próbować (czas próby), testować, sprawdzać, badać". Probacja określana jest jako forma sankcji kryminalnej, która zostaje nałożona przez sąd na sprawcę czynu po ogłoszeniu wyroku uznającego sprawcę winnym, jednakże bez orzeczenia bezwzględnej kary ${ }^{3}$. Nieodzownie związana jest z resocjalizacją. Jako środek resocjalizacji w społeczeństwie opiera się na teorii, że najlepszym sposobem osiągnięcia celu jest organizowanie sankcji kryminalnych w konkretnej zbiorowości, gdy jest to uzasadnione funkcjami kary. Zakłada się, że dana osoba nauczy się żyć w społeczności, a nie w sztucznym i oderwanym środowisku, jakim jest instytucja więzienia. Probacja jako środek resocjalizacji oparty na społeczeństwie, w połączeniu z sensownym zaangażowaniem społecznym, zapewnia wymagane oddziaływanie społeczne, ekonomiczne oraz osobowościowe $^{4}$. A. Marek wskazuje na następujące warunki środka probacyjnego:

1. musi być przewidzianą $\mathrm{w}$ ustawie formą reakcji na popełnione przestępstwo (wykroczenie - K.L.), opartą na stwierdzeniu winy jego sprawcy;

2. przesłanką jego orzekania musi być pozytywna prognoza kryminologiczna, pozwalająca na odstąpienie od orzekania lub wykonania kary;

3. środek ten musi przewidywać okres próby i uzależniać skutki prawne od przebiegu próby, to jest musi mieć charakter warunkowy,

4. okres próby musi być związany z nałożeniem na sprawcę określonych obowiązków, ewentualnie stosowaniem innych środków karnych;

5. istotnym jego elementem jest dozór kuratora nad poddanym próbie albo przynajmniej możliwość orzeczenia takiego dozoru w zależności od oceny przez sąd konieczności jego stosowania ${ }^{5}$.

O ile w prawie karnym wyróżnić możemy trzy rozbudowane rodzaje środków o charakterze probacyjnym: warunkowe umorzenie postępowania karnego, warunkowe zawieszenie wykonania kary, warunkowe przedterminowe zwolnienie ${ }^{6}$, o tyle w prawie wykroczeń jedynym środkiem związanym z poddaniem sprawcy próbie jest warunkowe zawieszenie wykonania kary aresztu ujęte przez ustawodawcę w art. 42 k.w. Jolanta Jakubowska-Hara wskazuje jednak, że gdyby uwzględnić

2 Ibidem, s. 932-933.

3 Zob. A. Bałandynowicz, Probacja. System sprawiedliwego karania, Warszawa 2002, s. 9.

4 Ibidem, s. 15.

5 A. Marek, op. cit., s. 937.

${ }^{6}$ Zdaniem A. Marka do środków probacyjnych zaliczyć należy jedynie warunkowe umorzenie postępowania i warunkowe zawieszenie wykonania kary, natomiast warunkowe przedterminowe zwolnienie z reszty kary pozbawienia wolności jest odrębnym środkiem polityki karnej i penitencjarnej — zob. ibidem, s. 937. 
wszystkie kryteria wskazane przez A. Marka, to nawet ten środek probacyjny nie spełniałby właściwych przesłanek ${ }^{7}$. Jednak przyjąć należy, że wyznaczenie okresu próby i uzależnienie dalszych skutków prawnych od przebiegu okresu próby pozwala na uznanie warunkowego zawieszenia wykonania kary aresztu za środek probacyjny, który został dość nieudolnie włączony przez ustawodawcę do kodeksu wykroczeń.

Warunkowe zawieszenie wykonania kary jest środkiem karnoprawnym za popełnienie przestępstwa (wykroczenia - K.L.) o walorach szczególnoprewencyjnych $^{8}$. Zwrócić należy uwagę, że podstawą stosowania tej instytucji w prawie karnym jest przede wszystkim pozytywna prognoza kryminologiczna, która zakłada, że sprawca nie powróci na drogę przestępczą, mimo że orzeczona kara nie zostanie wykonana. Zofia Sienkiewicz zauważa, że sprawca otrzymuje szansę, że orzeczona kara nie zostanie wykonana, jeżeli będzie w okresie próby przestrzegał wszystkich ustalonych przez sąd warunków, a przede wszystkim porządku prawnego. Ta w istocie „kontrolowana” wolność ma wiele pozytywnych cech, nie izoluje sprawcy od środowiska rodzinnego i zawodowego, a równocześnie przez nałożenie na sprawcę obowiązków probacyjnych i dozoru oraz dostosowanie ich do indywidualnego przypadku umożliwia realizację celów penalnych, a przede wszystkim celów szczególnoprewencyjnych ${ }^{9}$.

Do systemu polskiego prawa wykroczeń warunkowe zawieszenie wykonania kary aresztu zostało wprowadzone ustawą o przekazaniu niektórych drobnych przestępstw jako wykroczeń do orzecznictwa karno-administracyjnego z 17 czerwca 1966 roku $^{10}$, której celem była zmiana w postrzeganiu odpowiedzialności za wykroczenia i zbliżenia ich w sposób wyraźny do gałęzi prawa karnego przez rozpoczęcie procesu ,przepoławiania” czynów zabronionych jako przestępstwa do wykroczeń (kradzież, paserstwo, czyny spekulacyjne), uzależniając przyjęcie wykroczenia bądź przestępstwa od wartości przedmiotu lub wysokości szkody oraz zauważalne odejście od nadawania administracyjnego charakteru orzecznictwu kolegiów do spraw wykroczeń. Ustawa ta, w art. 28 ust. 5, dokonała zmiany w przepisach ustawy z dnia 15 grudnia 1951 roku o orzecznictwie karno-administracyjnym, dodając art. 9b, który wprowadził do systemu wykroczeń instytucję warunkowego zawieszenia wykonania kary aresztu, przy spełnieniu przesłanek tam wskazanych. Instytucję warunkowego zawieszenia wykonania kary aresztu można było zastosować, jeżeli ze względu na okoliczności popełnienia wykroczenia, właściwości i warunki osobiste sprawcy oraz jego zachowanie się po popełnieniu wykroczenia należało przypuszczać, że mimo niewykonania kary nie

7 J. Jakubowska-Hara, [w:] Reforma prawa wykroczeń, t. 1, red. P. Daniluk, Warszawa 2019, s. 329-330.

${ }^{8}$ Z. Sienkiewicz, [w:] Prawo karne materialne. Część ogólna i szczególna, red. M. Bojarski, J. Giezek, Z. Sienkiewicz, Warszawa 2007, s. 323.

9 Ibidem.

10 Dz.U. z 1966 r. Nr 23, poz. 149. 
popełni on nowego wykroczenia tego samego rodzaju. Znamienne dla środków probacyjnych jest wyznaczenie sprawcy okresu próby. Okres próby, jaki przyjął ustawodawca odnośnie do wykroczeń, nie mógł być krótszy niż sześć miesięcy i nie mógł przekroczyć roku. Rozpoczynał się on od uprawomocnienia się orzeczenia. Jeżeli wykroczeniem została wyrządzona szkoda w mieniu społecznym, warunkowe zawieszenie wykonania kary mogło być orzeczone tylko wtedy, gdy szkoda została w całości pokryta. Warunkowe zawieszenie wykonania kary aresztu nie miało zastosowania w przypadku sprawcy, który w ciągu dwóch lat przed popełnieniem wykroczenia był już karany za przestępstwo lub wykroczenie tego samego rodzaju. Zwrócić należy uwagę, że w przeciwieństwie do kodeksu karnego kodeks wykroczeń nie przewidywał i nadal nie przewiduje możliwości warunkowego zawieszenia wykonania innych kar. Co znamienne, art. $9 \mathrm{~b}$ ust. 5 cytowanej ustawy zawierał wprost unormowanie, że instytucja ta nie ma zastosowania do zastępczej kary aresztu. Pierwotny kształt tej instytucji został z niewielkimi zmianami wprowadzony do kodeksu wykroczeń. Obecnie warunkowe zawieszenie wykonania kary aresztu znajduje unormowanie w art. 42 k.w., który stanowi, że wykonanie kary aresztu można warunkowo zawiesić, jeżeli ze względu na okoliczności popełnienia wykroczenia, właściwości i warunki osobiste sprawcy oraz jego zachowanie się po popełnieniu wykroczenia należy przypuszczać, że mimo niewykonania kary nie popełni on nowego podobnego przestępstwa lub wykroczenia. Jeżeli wykroczeniem została wyrządzona szkoda w mieniu, warunkowe zawieszenie wykonania kary może być orzeczone tylko wtedy, gdy szkoda została w całości naprawiona. Okres próby pozostał niezmieniony i wynosi nie mniej niż sześć miesięcy i nie więcej niż rok. Obecnie brakuje ustawowego zapisu dotyczącego niemożności zastosowania środka probacyjnego do zastępczej kary aresztu, jednak nie budzi wątpliwości, że instytucja ta związana jest jedynie z karą zasadniczą aresztu, nie zaś z karą zastępczą. Podstawy orzeczenia kary zastępczej aresztu uregulowane zostały bowiem w art. 23 i 25 k.w. i żaden z tych przepisów nie odnosi się do możliwości warunkowego zawieszenia wykonania kary zastępczej. Ponadto warunkowe zawieszenie wykonania kary aresztu następuje w orzeczeniu o ukaraniu, a nie w postępowaniu wykonawczym ${ }^{11}$.

Należy podkreślić, że w doktrynie wątpliwość budzi samo stosowanie kary aresztu wobec sprawców wykroczeń ${ }^{12}$, a specyfika tej kary skłania do refleksji nad zasadnością, w związku z powyższym, utrzymywania w kodeksie wykroczeń instytucji warunkowego zawieszenia wykonania tej kary. Śledząc historię kar za wykroczenia, dostrzec możemy, że kara aresztu jako reakcja na popełnione wy-

11 J. Sawicki, $W$ sprawie warunkowego zawieszenia kary aresztu, „Nowa Kodyfikacja Prawa Karnego" 25, 2009, s. 97.

12 Zob. między innymi A. Marek, System kar i zasad ich wymiaru. Uwagi w zwiazku z reforma prawa o wykroczeniach, „Zagadnienia Wykroczeń” 1989, nr 4-5, s. 40; M. Melezini, [w:] Kary i środki..., s. 373. 
kroczenie istnieje, od kiedy ustawodawca podjął próby unormowania wykroczeń w Polsce po odzyskaniu przez Polskę niepodległości. Przewidywały ją rozporządzenie Prezydenta RP z dnia 11 lipca 1932 roku — Prawo o wykroczeniach ${ }^{13}$, jak również rozporządzenie Prezydenta Rzeczypospolitej z dnia 11 lipca 1932 roku — Kodeks karny ${ }^{14}$ jako łagodniejszą formę kary pozbawienia wolności. Początkowo areszt mógł być wymierzany w granicach od jednego dnia do trzech miesięcy. Zmieniano jego wymiar, by ostatecznie wyniósł od 5 do 30 dni. W historii miały też miejsce próby zniesienia kary aresztu. Na mocy ustawy o orzecznictwie karno-administracyjnym z 15 grudnia 1951 roku za wykroczenia kara aresztu została zniesiona, a w jej miejsce ustawodawca wprowadził karę pracy poprawczej. Jednakże kara pracy poprawczej nie zdała egzaminu i na mocy ustawy z 2 grudnia 1958 roku $^{15}$ przywrócono karę aresztu, którą kolegia do spraw wykroczeń mogły orzekać w przypadkach taksatywnie wymienionych w ustawie. Kara aresztu znalazła się także w kodeksie wykroczeń z 1971 roku jako kara zasadnicza ${ }^{16}$.

Zgodnie z założeniem inicjatorów kodeksu wykroczeń kara aresztu jest środkiem represji o wyjątkowym charakterze i ustawodawca ogranicza możliwość jej orzekania ${ }^{17}$. Jak wskazuje Janusz Sawicki, w praktyce orzeczniczej kolegia do spraw wykroczeń traktowały zasadniczą karę aresztu jako wyjątkową, co można dostrzec choćby w fakcie, że jej wymiar nie przekraczał 1,5\% ogółu orzeczonych kar zasadniczych. Twierdzi on, że w liczbach bezwzględnych wahania w stosowaniu tej kary były jednak znaczne, co da się wyjaśnić sytuacją społeczno-polityczną i wykorzystywaniem prawa wykroczeń także do celów politycznych, na przykład w 1982 roku orzeczono karę aresztu wobec 10163 sprawców (stan wojenny), a w 1984 roku już tylko w stosunku do 3928 osób $^{18}$. Obecnie kara aresztu orzekana jest w marginalnym zakresie i średnio nie przekracza ona $0,5 \%$ ogółu kar orzekanych w sprawach o wykroczenia.

Wyjątkowość kary aresztu została podkreślona przez ustawodawcę w dyspozycji art. 35 ustawy, który wskazuje, że jeżeli ustawa daje możliwość wyboru między aresztem a inną karą, areszt można orzec tylko wtedy, gdy czyn popełniono umyślnie, a zarazem za orzeczeniem kary aresztu przemawia jego waga lub okoliczności sprawy świadczące o demoralizacji sprawcy albo sposób jego działania zasługujący na szczególne potępienie. Ta formalna przesłanka jest o tyle istotna, że wymaga ustalenia formy czynu, ograniczając możliwość wymierzenia kary aresztu

13 Dz.U. z 1932 r. Nr 60, poz. 572.

14 Dz.U. z 1932 r. Nr 60, poz. 571 ze zm.

15 Dz.U. z 1958 r. Nr 77, poz. 396.

16 Zob. K. Liżyńska, A. Płońska, [w:] Wspótczesne przekształcenia sankcji karnych - zagadnienia teorii, wyktadni i praktyki stosowania, red. P. Góralski, A. Muszyńska, Warszawa 2018, s. 351.

17 Prawo o wykroczeniach (projekt), Warszawa 1970, s. 106.

18 Zob. J. Sawicki, op. cit., s. 92. 
za wykroczenia popełnione wyłącznie umyślnie. Warto zaznaczyć, że w prawie wykroczeń nie ma wykroczenia, które zagrożone jest wyłącznie karą aresztu, zatem hipoteza wyrażona w art. 35 k.w. jest spełniona zawsze ${ }^{19}$. Podkreślić należy, że dodatkowo w przypadku ferowania kary aresztu wystąpić musi co najmniej jedna z przesłanek art. 35 k.w., to jest waga czynu, demoralizacja sprawcy bądź zasługujący na szczególne potępienie sposób działania sprawcy ${ }^{20}$. Kolejnym argumentem świadczącym o wyjątkowości kary aresztu jest ustawowe ograniczenie wynikające z art. 26 k.w. Kary aresztu nie stosuje się (nawet jako kary zastępczej), gdy warunki osobiste sprawcy uniemożliwiają jej odbycie. Pod ustawowym określeniem warunków osobistych należy rozumieć szeroki katalog różnego rodzaju sytuacji życiowych. Pojęcie „uniemożliwienie odbycia kary” rozumiane jest szeroko, z uwzględnieniem aspektu zarówno humanitarnego, jak i społecznego, i odnosi się do takich okoliczności, jak ciężki stan zdrowia, niepełnosprawność ruchowa czy konieczność sprawowania opieki nad ciężko chorym członkiem rodziny ${ }^{21}$. Nie bez znaczenia jest także aspekt społecznego odbioru ewentualnego ukarania aresztem sprawcy wykroczenia, któremu właściwości psychofizyczne lub jego sytuacja życiowa uniemożliwiają odbycie takiej kary ${ }^{22}$.

Mając na uwadze powyższe ustawowe ograniczenia, wydaje się, że zastosowanie probacji w takich okolicznościach budzi zastrzeżenia. Instytucja warunkowego zawieszenia wykonania kary aresztu stanowi przecież dopełnienie regulacji z art. 35 k.w., a podstawową przesłanką do jej zastosowania jest pozytywna prognoza kryminologiczna wobec sprawcy. Indywidualnoprewencyjne rozumienie celów kary wyraża się w przekonaniu, że mimo niewykonania kary sprawca nie popełni w przyszłości podobnego przestępstwa lub wykroczenia ${ }^{23}$.

Kierując się dyspozycją art. $42 \S 1$ k.w. w przypadku orzeczenia kary aresztu, sąd ma obowiązek rozważyć, czy osoba, wobec której orzeczono areszt, może ze względu na pozytywną prognozę kryminologiczną — tej kary efektywnie nie odbyć $^{24}$. Odwołuje się zatem do przesłanek, które mają charakter ocenny.

Adam Błachnio przedstawione przez ustawodawcę w art. $42 \S 1$ k.w. przesłanki dzieli na te, które:

1. dotyczą zachowania sprawcy i okoliczności mu towarzyszących,

2. są związane stricte ze sprawcą,

19 W. Radecki, [w:] M. Bojarski, W. Radecki, Kodeks wykroczeń. Komentarz, Warszawa 2013, s. 338.

${ }^{20}$ M. Bojarski, [w:] M. Bojarski, A. Płońska, Z. Świda, Podstawy materialnego i procesowego prawa o wykroczeniach, Wrocław 2012, s. 94.

21 T. Bojarski, [w:] Kodeks wykroczeń. Komentarz, red. T. Bojarski, Warszawa 2015, s. 77 n.

22 V. Konarska-Wrzosek, [w:] System Prawa Karnego, t. 5. Nauka o karze. Sadowy wymiar kary, red. T. Kaczmarek, Warszawa 2015, s. 329.

23 J. Jakubowska-Hara, op. cit., s. 331.

24 A. Gubiński, [w:] Prawo wykroczeń, red. A. Gubiński, T. Grzegorczyk, Warszawa 1996, s. 165. 
3. odnoszą się do zachowania po popełnieniu wykroczenia, przy czym kumulatywnie muszą one prowadzić do tak zwanej pozytywnej prognozy kryminologicznej, a więc przekonania, że sprawca ponownie nie popełni wykroczenia lub przestępstwa ${ }^{25}$.

Zgodzić należy się z A. Błachniem, że okoliczności wymienione w punkcie pierwszym mogą mieć charakter zarówno łagodzący, przemawiający za warunkowym zawieszeniem wykonania kary aresztu, jak i obciążający, a więc przemawiający przeciwko powyższemu ${ }^{26}$. Do tych okoliczności zaliczymy przecież wagę czynu, rozmiar szkody, rozmiar naruszonych obowiązków, motywację sprawcy czy postać zamiaru. Właściwości i warunków sprawcy, ujętych w punkcie 2, mogących leżeć u podstaw warunkowego zawieszenia wykonania kary aresztu, nie należy utożsamiać z popełnionym wykroczeniem. Do właściwości sprawcy, które mogą wpływać na decyzję sądu odnośnie do zastosowania omawianego środka probacyjnego, zaliczyć należy przymioty ściśle związane z osobą sprawcy, takie jak poziom rozwoju umysłowego, stan zdrowia, cechy psychofizyczne, postawę wobec wartości społecznych, stopień ich utrwalenia czy w końcu istnienie lub stopień demoralizacji ${ }^{27}$. W przeciwnym razie, gdyby wziąć pod uwagę warunki sprawcy związane z popełnionym wykroczeniem, nie byłoby możliwe zastosowanie instytucji warunkowego zawieszenia wykonania kary aresztu, gdyż jeżeli sąd zdecydowałby się na wymierzenie kary aresztu, dlatego że okoliczności sprawy świadczyłyby o demoralizacji sprawcy, to o pozytywnej prognozie trudno w ogóle mówić, jest ona $\mathrm{z}$ reguły negatywna ${ }^{28}$. Jeżeli zaś chodzi o trzeci ze wskazanych warunków, odnoszący się do zachowania sprawcy po popełnieniu wykroczenia, istotne jest zbadanie, czy sprawca żałuje tego, co zrobił, czy ma wyrzuty sumienia, czy współczuł ofierze, czy zatroszczył się o jej los, czy przeprosił, czy prosił o przebaczenie, czy przyrzekał, że więcej tego nie zrobi, czy sam doniósł o popełnionym przez siebie czynie ${ }^{29}$. Nie chodzi przy tym o to, aby nabrać pewności, że sprawca będzie w ogóle szanował prawo i zasady współżycia społecznego (jak w art. $36 \mathrm{k}$.w. w odniesieniu do niezbędnej przesłanki wyboru kary nagany), ale tylko o przekonanie, że sprawca nie stanie się recydywistą, czyli nie popełni nowego przestępstwa lub wykroczenia ${ }^{30}$.

Nie budzi wątpliwości, że wszystkie z trzech omawianych warunków muszą wystąpić łącznie, by skorzystać z dobrodziejstwa warunkowego zawieszenia wy-

25 A. Błachnio, Warunkowe zawieszenie wykonania kary aresztu na podstawie ustawy z dnia 20 maja 1971 r. Kodeks wykroczeń, „Probacja” 2016, nr 4, s. 52.

26 Ibidem.

27 Zob. A. Zoll, [w:] Kodeks karny. Część ogólna, t. 1. Komentarz do art. 1-52, red. W. Wróbel, A. Zoll, Warszawa 2016, s. 182.

28 W. Radecki, op. cit., s. 366.

29 Zob. V. Konarska-Wrzosek, [w:] Kodeks karny. Komentarz, red. R.A. Stefański, Warszawa 2015, s. 374.

30 J. Sawicki, op. cit., s. 98. 
konania kary aresztu. Jednak nawet przy spełnieniu tych przesłanek należy mieć na względzie, że stosowanie kary aresztu następuje, zgodnie z regułą wyrażoną w art. 35 k.w., w zasadzie w stosunku do zdemoralizowanych sprawców, gdy działanie sprawcy nacechowane jest szczególnym potępieniem bądź gdy waga czynu przemawia za zasadnością kary wykonanej w warunkach izolacji, stąd znalezienie uzasadnienia zastosowania instytucji warunkowego zawieszenia wykonania kary aresztu jest trudne. Jeżeli organ orzekający przy wyborze kary zdecydował się na orzeczenie kary aresztu, nie znajdując podstaw do zastosowania innej kary, to trudno wyobrazić sobie, że w stosunku do tego sprawcy istnieją przesłanki łagodniejszego jego potraktowania przez zastosowanie warunkowego zawieszenia wykonania kary aresztu ${ }^{31}$. Podmiotowe i przedmiotowe przesłanki orzekania kary aresztu (art. 35 k.w.) kształtują się zgoła odmiennie od dyspozycji art. 42 § 1 k.w., a jednoznacznie negatywny wydźwięk przesłanek leżących u podstaw wymierzenia kary aresztu pozostaje w sprzeczności z pozytywnymi rokowaniami wobec sprawcy, które uzasadniałyby warunkowe zawieszenie tej kary ${ }^{32}$.

Postulowane na etapie wprowadzania do kodeksu wykroczeń propozycje uzależnienia warunkowego zawieszenia wykonania kary aresztu od nadzoru nad tą instytucją uprawnionych organów czy zadośćuczynienia nie tylko pokrzywdzonemu, ale także społeczeństwu przez wykonywanie na przykład pracy społecznie użytecznej, zobowiązania do naprawienia szkody, przeproszenia pokrzywdzonego, jak również przez wprowadzenie obowiązków wychowawczych, oddziałujących wprost na sprawcę, na przykład powstrzymywanie się od nadużywania alkoholu, zobowiązanie do wykonywania pracy zarobkowej, nie spotkały się z aprobatą prawodawcy ${ }^{33}$. Owszem, w projektach prawa wykroczeń odnoszących się do warunkowego zawieszenia wykonania kary aresztu próbowano wprowadzać elementy probacji, na przykład uzależniając jej zastosowanie od uprzedniej zgody sprawcy, co słusznie zostało poddane krytyce ${ }^{34}$, czy też wprowadzając dodatkowo możliwość orzeczenia kary grzywny przy zastosowaniu tej instytucji. Jednak przyjęty model warunkowego zawieszenia wykonania kary aresztu, poza wyznaczeniem okresu próby, pozbawiony jest wszelkich elementów probacyjnych. A. Marek słusznie wskazuje, iż w świetle doświadczeń prawa karnego taki model uważa się za mało skuteczny ${ }^{35}$. Sprawca bowiem, nie odczuwając żadnej dolegliwości i żadnej kontroli po wydaniu orzeczenia ferującego karę aresztu $z$ warunkowym zawieszeniem wykonania tejże kary, może poczuć się bezkarny.

31 M. Bojarski, op. cit., s. 96.

32 J. Jakubowska-Hara, op. cit., s. 333.

33 Zob. A. Gubiński, Warunkowe zawieszenie wykonania kary aresztu. (Stan obecny i perspektywy rozwoju instytucji), „Zagadnienia Wykroczeń” 1980, nr 2, s. 26.

34 Jerzy Szumski słusznie stwierdził, że można mieć wątpliwości, czy zgoda taka będzie dobrowolna, skoro sprawca w obliczu grożącej mu kary aresztu znajduje się w sytuacji przymusowej, nakazującej mu wybór mniejszego zła — J. Szumski, O niektórych środkach karnych w projekcie reformy prawa wykroczeń, „Państwo i Prawo” 1990, nr 11, s. 97 n.

35 A. Marek, Prawo wykroczeń (materialne i procesowe), Warszawa 2004, s. 108. 
Kontrowersje odnośnie do stosowania probacji przy karze aresztu wynikają także z tego, że w przypadku wykroczeń mamy do czynienia z tak zwanym prostym zawieszeniem wykonania kary, nieobwarowanym żadnymi dodatkowymi obowiązkami leżącymi po stronie sprawcy czy też kontrolą, co mając na względzie przesłanki stosowania tej kary, wzbudza przeświadczenie o sprzeczności tej instytucji z założeniami i celami kary aresztu. Rezygnacja przez ustawodawcę z właściwych prawu karnemu elementów mających charakter probacyjny (wyznaczenie sprawcy w okresie próby dodatkowych obowiązków, możliwość orzeczenia dozoru kuratora) pozbawia w wykroczeniach tę instytucję możliwości efektywnej realizacji i rodzi niebezpieczeństwo potraktowania jej jako swoistego uwolnienia od kary i poczucia bezkarności sprawcy. Sama groźba wykonania zawieszonej kary w przypadku popełnienia podobnego przestępstwa lub wykroczenia w okresie próby (zresztą stosunkowo krótkim, to jest od 6 miesięcy do roku) nie stanowi wystarczającego warunku skuteczności tej instytucji ${ }^{36}$. Wskazany przez ustawodawcę okres próby jest krótki, ale sama długość okresu próby nie budzi zastrzeżeń. Oczywiście, że im więcej okoliczności przemawia za pozytywną prognozą, tym krótszy może być okres próby, aczkolwiek ze względów praktycznych raczej powinien on być orzekany w granicach maksymalnych — jednego roku ${ }^{37}$. A. Błachnio słusznie podkreśla, że długość tego okresu powinna być również uzależniona od charakteru samego czynu - im większy ładunek bezprawności on zawierał, tym również okres próby powinien być dłuższy ${ }^{38}$.

Ustawowym, a nie ocennym warunkiem możliwości skorzystania z instytucji warunkowego zawieszenia wykonania kary aresztu jest naprawienie w całości szkody, jeżeli wykroczeniem została wyrządzona szkoda w mieniu. Słusznie jednak wskazuje Olga Sitarz, że warunek ten musi być spełniony nie tylko w przypadku wykroczeń przeciwko mieniu, ale dotyczy każdego wykroczenia, z którego popełnieniem wiąże się szkoda ${ }^{39}$. W art. $42 \S 3 \mathrm{k}$.w., który reguluje omawianą kwestię, brak jednak wyraźnego stwierdzenia, że szkodę powinien wyrównać sam sprawca (własnym czynem czy też ze środków należących do niego), co sprawia, że przedmiotowa przesłanka jest spełniona także wtedy, gdy szkodę naprawiła inna osoba. W takiej jednak sytuacji, kiedy sprawca nie przyczynił się do naprawienia szkody, przesłanka pozytywnej prognozy (ze względu na ,jego zachowanie się po popełnieniu wykroczenia”) jest mocno wątpliwa ${ }^{40}$.

Fakultatywne zakazy stosowania warunkowego zawieszenia wykonania kary aresztu można wywieść z art. 43 k.w. Wykonania kary aresztu nie można warunkowo zawiesić w stosunku do sprawcy działającego w warunkach recydywy oraz sprawcy, który popełnił wykroczenie o charakterze chuligańskim. Abstrahując od
36 Ibidem, s. 332.
37 W. Radecki, op. cit., s. 367.
38 A. Błachnio, op. cit., s. 57.
39 O. Sitarz, Materialne prawo wykroczeń. Część ogólna, Warszawa 2015, s. 147.
40 W. Radecki, op. cit. 
częstej niemożności, w sprawach o wykroczenia, potwierdzenia działania sprawcy w warunkach recydywy (brak wpisu do Krajowego Rejestru Karnego, gdy sprawcy wymierzono karę inną aniżeli areszt), także przyjęte rozwiązanie dotyczące popełnienia przez sprawcę czynu o charakterze chuligańskim budzi poważne wątpliwości w zakresie zasadności egzystowania tej instytucji w przepisach kodeksu wykroczeńn ${ }^{41}$. Tym, co jednak zwraca uwagę i świadczy o niekonsekwencji ustawodawcy, jest zapis ustawy, który pozwala sądowi na zastosowanie instytucji probacyjnej także przy zaistnieniu przedmiotowego, ustawowego przecież zakazu, jeżeli uzna to za celowe. O ile intencją ustawodawcy było najwyraźniej złagodzenie przedmiotowych zakazów, a w efekcie pewne uelastycznienie przepisów służące prewencji szczególnej, o tyle dla prewencji ogólnej wydźwięk tego zapisu nie jest już tak korzystny. Taki rodzaj legislacji, jaki przedstawiono w art. 43 k.w., może wywołać wrażenie, że regulacja ta jest zbędna. W istocie bowiem wystąpienie przesłanki negatywnej, z uwagi na jej względny charakter, nie wiąże sądu w zakresie dopuszczalności zastosowania instytucji warunkowego zawieszenia wykonania kary aresztu, a co najwyżej obliguje do wyjaśnienia w uzasadnieniu przyczyn pominięcia tych zakazów. W praktyce oznacza to swobodę sądu mimo ustawowych zakazów i stawia pod znakiem zapytania sens regulacji wynikającej z art. 43 k.w. ${ }^{42}$

Kolejnym mankamentem instytucji warunkowego zawieszenia wykonania kary aresztu jest przyjęcie jednego tylko kryterium oceny — czy wyznaczona próba była nieudana, czy też udana. Jest to fakt popełnienia albo niepopełnienia przestępstwa lub wykroczenia ${ }^{43}$. Można stwierdzić, że przyjmując prosty model warunkowego zawieszenia wykonania kary aresztu, kodeks wykroczeń przyjmuje także prosty model zarządzenia kary w przypadku nieudanej próby. Ustawa wskazuje, że obligatoryjne zarządzenie kary nastąpi, gdy sprawca w okresie próby popełni podobne wykroczenie lub przestępstwo, a fakultatywne, w przypadku popełnienia przez sprawcę w okresie próby innego przestępstwa lub wykroczenia (art. $44 \S 1$ i 2 k.k. $)^{44}$. Kolejne przestępstwo bądź wykroczenie, którego sprawca się dopuścił, musi być popełnione w okresie próby, zatem po uprawomocnieniu się orzeczenia, w którym zastosowano instytucję probacyjną. Obowiązująca w postępowaniu o wykroczenie zasada domniemania niewinności wskazuje, że podstawą do zarządzenia kary może być niewątpliwie prawomocne orzeczenie, stwierdzające popełnienie nowego wykroczenia lub przestępstwa. Podstawy tej nie może stanowić jedynie powzięta przez sąd decyzja o toczącym się postępowaniu wobec sprawcy, wobec

${ }^{41}$ K. Liżyńska, Ksztaltowanie się kary aresztu w polskim prawie wykroczeń, „Prokuratura i Prawo" 2013, nr 2, s. 15.

42 J. Sawicki, op. cit., s. 102.

43 Zob. W. Radecki, op. cit., s. 369.

${ }^{44}$ Zwrócić należy uwagę, że potwierdzeniem popełnienia wykroczenia nie będzie jedynie orzeczenie sądu, może nim być mandat wydany w drodze postępowania mandatowego przewidzianego przez kodeks wykroczeń. 
którego zastosowano instytucję warunkowego zawieszenia wykonania kary aresztu bądź nieprawomocne nowe skazanie ${ }^{45}$. O ile obligatoryjne przesłanki zarządzenia wykonania kary aresztu nie budzą zastrzeżeń, o tyle fakultatywne zarządzenie tejże kary ma charakter stricte ocenny. Ustawodawca, podnosząc, że fakultatywne zarządzenie wykonania kary aresztu może nastąpić w przypadku popełnienia przez sprawcę w okresie próby innego przestępstwa lub wykroczenia, nie daje wskazówek co do charakteru nowego czynu karalnego ani też nie wskazuje, jakie czynniki sąd powinien uwzględniać, decydując o „odwołaniu” warunkowego zawieszenia wykonania kary. Formalnie rzecz biorąc, nie mają znaczenia postać i stopień winy, stopień społecznej szkodliwości czynu ani rodzaj naruszonego dobra. Bez wątpienia jednak wszystkie te czynniki powinny mieć w opisywanej sytuacji decydujące znaczenie $^{46}$. Brak także w kodeksie wykroczeń przepisu, jaki uczynił ustawodawca w kodeksie karnym, a co z punktu widzenia oceny prognozy kryminologicznej sprawcy wydaje się uzasadnione, że zarządzenie wykonania warunkowo zawieszonej kary może nastąpić, gdy sprawca rażąco narusza porządek prawny, przy czym ujęte w kodeksie karnym pojęcie „rażącego naruszenia porządku prawnego" to niekoniecznie popełnienie innego wykroczenia bądź przestępstwa, jak zostato to ujęte przez ustawodawcę w kodeksie wykroczeń, lecz także inne zachowania sprawcy w okresie próby, niekoniecznie sprowadzające się do porządku w znaczeniu karnoprawnym. Może to być na przykład dopuszczenie się zachowania niebędącego czynem zabronionym pod groźbą kary, jak naruszenie innych obowiązków cywilnoprawnych, pracowniczych. Naruszeniem porządku prawnego, które skutkować może przyjęciem negatywnej prognozy kryminologicznej, a co za tym idzie skutkującym zarządzeniem wykonania kary uprzednio warunkowo zawieszonej za przestępstwo, jest zatem zachowanie się skazanego wbrew zakazom lub nakazom prawa karnego (popełnienie przestępstwa), administracyjnego (popełnienie wykroczenia), a także wbrew regułom, których przestrzeganie mieści się w granicach zadań i celów instytucji probacyjnych ${ }^{47}$.

Brak takiego unormowania stanowi niemożność zarządzenia warunkowo zawieszonej kary aresztu w przypadku rażącego naruszenia porządku prawnego przez sprawcę, niepotwierdzonego prawomocnym orzeczeniem za przestępstwo lub wykroczenie.

Zgodnie z art. $44 \S 3$ k.w., jeżeli w okresie próby i w ciągu dalszych dwóch miesięcy nie zarządzono wykonania kary, ukaranie uważa się za niebyłe. Wskazany przez ustawodawcę dwumiesięczny okres po zakończeniu okresu próby nie oznacza jakiegoś przedłużenia okresu próby, lecz jest to czas na formalne załatwienie sprawy zarządzenia wykonania kary ${ }^{48}$. Jeżeli okres próby okazał się udany

45 J. Sawicki, op. cit., s. 104.

46 J. Jakubowska-Hara, op. cit., s. 337.

47 Zob. postanowienie Sądu Apelacyjnego w Krakowie z dnia 14 maja 2019 roku, II AKzw 373/19, LEX 2738040.

48 W. Radecki, op. cit., s. 369. 
bądź mimo popełnienia w okresie próby nowego wykroczenia lub przestępstwa przez sprawcę we wskazanym okresie dwóch miesięcy od zakończenia okresu próby nie zarządzono warunkowo zawieszonej kary aresztu, ukaranie uważa się za niebyłe, zatem następuje zatarcie ukarania z mocy prawa.

Powyższa analiza instytucji warunkowego zawieszenia wykonania kary aresztu skłania do konkluzji, że zasadność utrzymania tego jedynego w wykroczeniach środka probacyjnego budzi poważne wątpliwości. Prosty model warunkowego zawieszenia wykonania kary aresztu, nieobarczony żadnymi obowiązkami po stronie sprawcy, jest niewystraczający do kontroli zasadności jego stosowania i nie spełnia swojego celu zarówno ogólno-, jak i szczególnoprewencyjnego, wzbudzając przeświadczenie o bezkarności sprawcy wykroczenia, spełniającego równocześnie przecież warunki do zastosowania wobec niego najsurowszej, wyjątkowej i obarczonej ustawowymi ograniczeniami kary. Przeniesienie na grunt kodeksu wykroczeń niepełnej regulacji warunkowego zawieszenia wykonania kary aresztu z kodeksu karnego okazuje się wątpliwe, a niekonsekwencje ustawodawcy wynikające przede wszystkim z relacji przesłanek leżących u podstaw wymierzania kary aresztu i przesłanek leżących u podstaw zastosowania środka probacyjnego są zbyt rażące i niezrozumiałe. Jeżeli organ wymierzający karę chce łagodniej potraktować sprawcę wykroczenia, może wymierzyć przecież inne przewidziane ustawą łagodniejsze kary, a nie wykonanie kary warunkowo zawiesić i pozostawiać odczucie bezkarności sprawcy. Za likwidacją warunkowego zawieszenia wykonania kary aresztu przemawia także malejące znaczenie warunkowego zawieszenia wykonania kary aresztu w polityce karnej sądów ${ }^{49}$. Kara aresztu z warunkowym zawieszeniem jej wykonania orzekana jest marginalnie. Podniesione powyżej okoliczności przemawiają za zmianami kodeksu wykroczeń w tym zakresie i rezygnacją z instytucji warunkowego zawieszenia wykonania kary $\operatorname{aresztu}^{50}$.

\section{PROBATION IN THE PETTY OFFENCES LAW - ABOUT THE NEED FOR CONDITIONAL SUSPENSION OF THE DETENTION EXECUTION}

\section{Summary}

The conditional suspension of the execution of an arrest sentence is the only probation measure in the case of petty offences. There is no doubt that it is not a necessary condition for the perpetrator to serve a sentence to achieve the objectives of both the sentence and the proceedings in the case of

49 J. Jakubowska-Hara, op. cit., s. 339.

$50 \mathrm{Za}$ rezygnacją $\mathrm{z}$ warunkowego zawieszenia wykonania kary aresztu opowiada się też Jolanta Jakubowska-Hara (ibidem, s. 337). Inni autorzy, jak A. Marek, Prawo wykroczeń..., op. cit., s. 108; J. Sawicki, op. cit., s. 106-107; oraz A. Błachnio, op. cit., s. 59, opowiadają się za utrzymaniem tego środka probacyjnego przy odpowiedniej jego modyfikacji. 
petty offenses. However, a wider analysis of the probation measure in question shows that the maintenance of the conditional suspension of the prison sentence execution in the code of petty offenses is doubtful. This is due to the contradiction between the prerequisites for the application of the arrest sentence and the application of the discussed institution, as well as the marginal application of this institution in practice.

Keywords: petty offenses, probation measure, detention, conditional suspension of the sentence, probation obligation, probation period

\section{BIBLIOGRAFIA}

Bałandynowicz A., Probacja. System sprawiedliwego karania, Warszawa 2002.

Błachnio A., Warunkowe zawieszenie wykonania kary aresztu na podstawie ustawy z dnia 20 maja 1971 r. Kodeks wykroczeń, „Probacja” 2016, nr 4.

Bojarski M., [w:] M. Bojarski, A. Płońska, Z. Świda, Podstawy materialnego i procesowego prawa o wykroczeniach, Wrocław 2012.

Bojarski T., [w:] Kodeks wykroczeń. Komentarz, red. T. Bojarski, Warszawa 2015.

Gubiński A., [w:] Prawo wykroczeń, red. A. Gubiński, T. Grzegorczyk, Warszawa 1996.

Gubiński A., Warunkowe zawieszenie wykonania kary aresztu. (Stan obecny i perspektywy rozwoju instytucji), „Zagadnienia Wykroczeń” 1980, nr 2.

Jakubowska-Hara J., [w:] Reforma prawa wykroczeń, t. 1, red. P. Daniluk, Warszawa 2019.

Konarska-Wrzosek V., [w:] Kodeks karny. Komentarz, red. R.A. Stefański, Warszawa 2015.

Konarska-Wrzosek V., [w:] System Prawa Karnego, t. 5. Nauka o karze. Sadowy wymiar kary, red. T. Kaczmarek, Warszawa 2015.

Liżyńska K., Ksztaltowanie się kary aresztu w polskim prawie wykroczeń, „Prokuratura i Prawo” 2013, $\mathrm{nr} 2$.

Liżyńska K., Płońska A., [w:] Współczesne przekształcenia sankcji karnych — zagadnienia teorii, wyktadni i praktyki stosowania, red. P. Góralski, A. Muszyńska, Warszawa 2018.

Marek A., [w:] System Prawa Karnego, t. 6. Kary i środki karne. Poddanie sprawcy próbie, red. M. Melezini, Warszawa 2010.

Marek A., Prawo wykroczeń (materialne i procesowe), Warszawa 2004.

Marek A., System kar i zasad ich wymiaru. Uwagi w zwiąku z reforma prawa o wykroczeniach, „Zagadnienia Wykroczeń” 1989, nr 4-5.

Melezini M., [w:] System Prawa Karnego, t. 6. Kary i środki karne. Poddanie sprawcy próbie, red. M. Melezini, Warszawa 2010.

Prawo o wykroczeniach (projekt), Warszawa 1970.

Radecki W., [w:] M. Bojarski, W. Radecki, Kodeks wykroczeń. Komentarz, Warszawa 2013.

Sawicki J., W sprawie warunkowego zawieszenia kary aresztu, „Nowa Kodyfikacja Prawa Karnego” $25,2009$.

Sienkiewicz Z., [w:] Prawo karne materialne. Część ogólna i szczególna, red. M. Bojarski, J. Giezek, Z. Sienkiewicz, Warszawa 2007.

Sitarz O., Materialne prawo wykroczeń. Część ogólna, Warszawa 2015.

Szumski J., O niektórych środkach karnych w projekcie reformy prawa wykroczeń, „Państwo i Prawo" 1990, nr 11.

Zoll A., [w:] Kodeks karny. Część ogólna, t. 1. Komentarz do art. 1-52, red. W. Wróbel, A. Zoll, Warszawa 2016. 


\section{AKTY PRAWNE}

Rozporządzenie Prezydenta Rzeczypospolitej z dnia 11 lipca 1932 roku — Prawo o wykroczeniach, Dz.U. z 1932 r. Nr 60, poz. 572.

Rozporządzenie Prezydenta Rzeczypospolitej z dnia 11 lipca 1932 roku — Kodeks karny, Dz.U. z 1932 r. Nr 60, poz. 571.

Ustawa z dnia 17 czerwca 1966 roku o przekazaniu niektórych drobnych przestępstw jako wykroczeń do orzecznictwa karno-administracyjnego, Dz.U. z 1966 r. Nr 23, poz. 149. 